Brit. J. industr. Med., 1952, 9, 74.

\title{
SKIN CANCER OF THE HAND AND FOREARM
}

\author{
BY \\ C. N. D. CRUICKSHANK and A. GOUREVITCH \\ From the Medical Research Council Industrial Medicine Research Unit, Birmingham Accident Hospital, \\ United Birmingham Hospitals
}

(RECEIVED FOR PUBLICATION AUgUST 20, 1951)

\begin{abstract}
A previous investigation (Cruickshank and Squire, 1950) demonstrated that a risk of skin cancer may occur in the engineering industry as a result of exposure to mineral oils. The conclusions were based upon the presence of hyperkeratoses observed upon the arms of machine operators, the biological testing of a commercial oil for tumour-producing activity, and a survey of the patients with scrotal cancer reporting to the United Birmingham Hospitals during the previous 10 years. The last part of this investigation yielded additional information concerning the natural history of scrotal cancer. It was decided to extend the enquiry by investigating cases of epithelioma of the hands and forearms which had reported to the same hospitals over a similar 10-year-period (1941-1950). Hands and forearms were selected as being also heavily exposed to any chemical carcinogens encountered during work. This investigation has yielded both clinical and aetiological information concerning skin cancer of the hands and forearms, and has enabled a comparison to be drawn between this condition and scrotal cancer.

Information was obtained from the Records Departments of the Queen Elizabeth and General Hospitals, Birmingham. The case records and histological reports of all patients treated for epithelioma of the hands and forearms were examined, patients were followed-up where possible, and if available the original sections were examined histologically in order to confirm the diagnosis.
\end{abstract}

\section{Findings}

During the 10-year-period under review 87 cases of cancer of the hands and forearms were found. Of these, 56 lived in the Birmingham area. The remainder had been referred to the United Birmingham Hospitals for treatment (mainly by the Radiotherapeutic Unit) from outside areas. The cases living outside Birmingham will not be considered further as they introduce an element of selection, and also because the follow-up proved to be unsatis- factory. Of the 56 Birmingham cases, 44 were male and the subsequent information refers only to these cases.

The main findings are set out in Table 1. This has been arranged exactly as in the investigation previously reported in order that comparisons may be easily drawn. The patients are classified in three categories according to the main agents encountered at their jobs.

It will be seen that of the 44,18 gave a history of exposure to various oils, six to pitch, and 13 were in other occupations. In seven instances no information was available. Of the first group, 14 had been employed in the engineering industry. (This number includes one patient employed as a store keeper, and hence classified in Table 2 in Order XXIX.) The remaining four were a motor driver, a brickmaker, a slater and tyler, and a gold and silver polisher. The duration of exposure to oil varied from eight to 48 years, giving a mean of 28 years (S.E. = 4).

Since the numbers in each of the three categories in Table 1 might be attributed to the fact that the total population of Birmingham was exposed to these agents in the same proportion, the patients have been further grouped by occupation according to the Registrar-General's classification into 32 Orders (Table 2). Figures for the number of males over 14 years of age employed in these Orders in the Birmingham area are available from the Census Report (1931) and consequently incidence figures may be calculated. These figures can be regarded as only approximate since the number of cases is small and no correction for age distribution within the Orders is possible. The use of population figures from the 1931 census, however, is particularly justifiable in view of the long latent period and the long exposure required to initiate the disease.

The classification itself is not entirely satisfactory for the present purpose, as the Orders are very broad and may contain several categories with widely varying occupational hazards. 
TABLE 1

ANAL'SIS OF 44 MALE PATIENTS WITH CANCER OF HANDS AND FOREARMS ATTENDING UNITED BIRMINGHAM HOSPITALS 1941-50

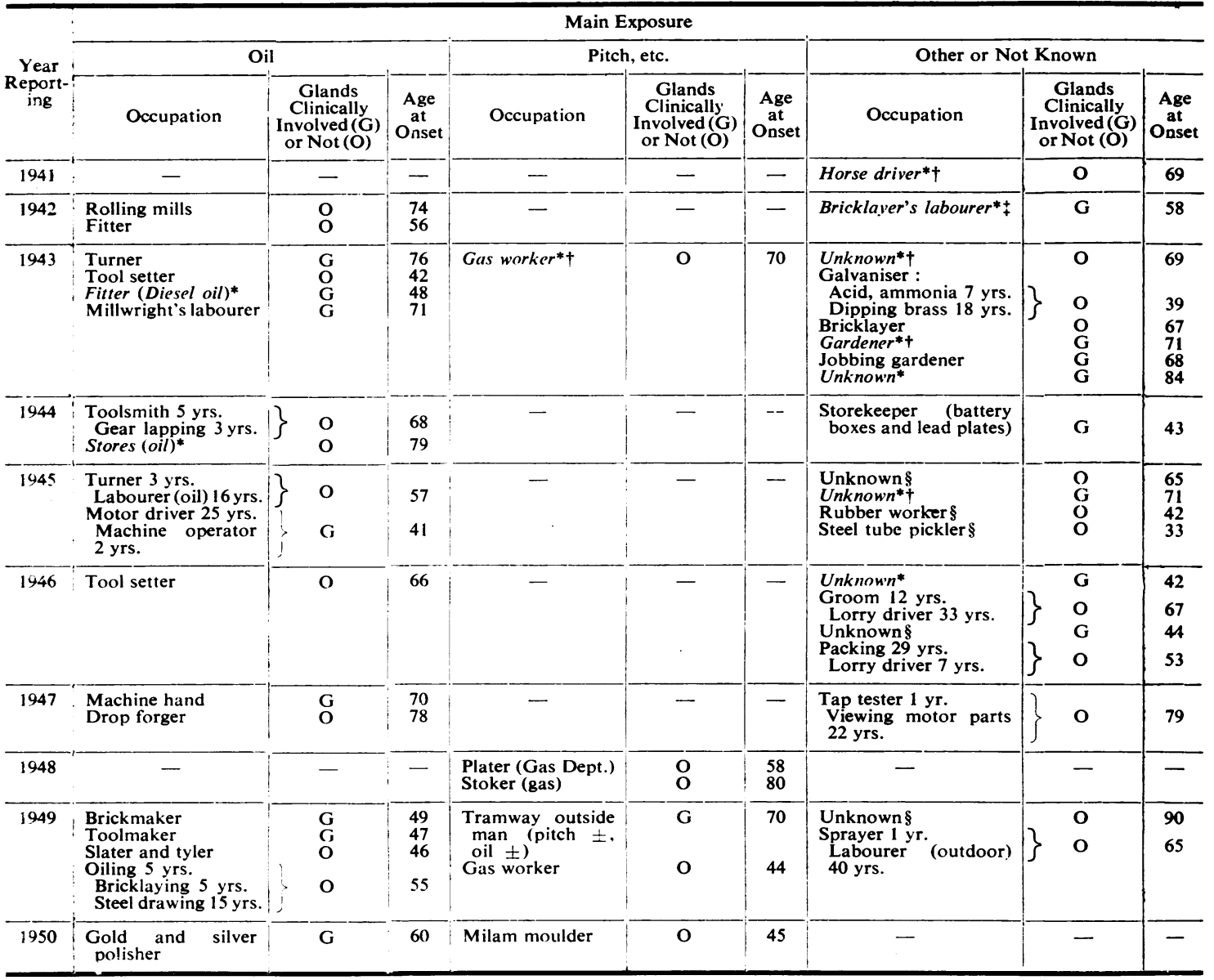

* (italics) Patient died by February, 1951

+ Cause of death apparently unrelated to carcinoma.

$\ddagger$ Cause of death unknown.

$\$$ Not established whether alive or dead by February, 1951.

TOTAL FINDINGS

\begin{tabular}{|c|c|c|c|c|c|}
\hline \multicolumn{3}{|c|}{ Exposure } & Patients & Deaths & Average Age \\
\hline Oil & . & . & $18(12)^{*}$ & $2(4)$ & $60(46)$ \\
\hline Pitch & $\ldots$ & . & $6(13)$ & $1(4)$ & $61(58)$ \\
\hline \multicolumn{2}{|c|}{ Other and doubtful } & .. & $20(9)$ & $7(1)$ & $61(61)$ \\
\hline \multicolumn{2}{|c|}{ Grand total } & . & $44(34)$ & $10(9)$ & 一 \\
\hline
\end{tabular}

* The figures in brackets are the corresponding figures for scrotal cancer from Cruickshank and Squire (1950).

Table 2 shows that, of the 37 cases in which the occupation was known, 16 occurred in Order VII as compared with 21 in all other Orders. This figure is significantly high $\left(\chi^{2}=4.3, P<0.05\right){ }^{*}$ Order
VII which has the general title of "metal workers" is very large in this area, and although there are many * In this and the subsequent $\chi^{2}$ calculations on page 78 , persons retired or not gainfully employed (Order XXXII) have not been included. 
TABLE 2

CLASSIFICATION BY OCCUPATION OF 37 MALE PATIENTS WITH HAND AND FOREARM CANCER

\begin{tabular}{|c|c|c|c|c|c|c|}
\hline \multirow{2}{*}{ Order } & \multirow{2}{*}{ Description } & \multirow{2}{*}{$\begin{array}{l}\text { Nos. } \\
\text { Em- } \\
\text { ployed } \\
\text { in } \\
\text { Birm- } \\
\text { ingham } \\
\text { (1931 } \\
\text { Census) }\end{array}$} & \multirow{2}{*}{ Cases } & \multicolumn{3}{|c|}{ Exposure of Cases } \\
\hline & & & & Oil & Pitch & Other \\
\hline I & Fishermen .. & 1 & $0(0)^{*}$ & - & - & - \\
\hline II & $\begin{array}{lllll}\text { Agricultural occupations .. } & \ldots & \ldots & \ldots & \ldots\end{array}$ & 3,115 & $2(0)$ & $0 \quad(0)$ & 0 (0) & $2(0)$ \\
\hline III & Mining and quarrying occupations $\quad \ldots \quad \ldots$ & 349 & $0 \quad(0)$ & - & - & - \\
\hline IV & $\begin{array}{l}\text { Workers in the treatment of non-metalliferous mine } \\
\text { and quarry products (includes gas workers) }\end{array}$ & 481 & 4 (7) & $0 \quad(0)$ & $4(7)$ & $0(0)$ \\
\hline $\mathbf{V}$ & Makers of bricks, pottery, and glass $\ldots$ & 1,615 & $1(0)$ & $1(0)$ & $0 \quad(0)$ & $0(0)$ \\
\hline VI & $\begin{array}{l}\text { Workers in chemical processes ; makers of paints, } \\
\text { oils, etc. }\end{array}$ & 752 & $0 \quad(0)$ & - & - & - \\
\hline VII & Metal workers (not electro plate or precious metals). . & 88,859 & $16(14)$ & $12(11)$ & $1(0)$ & 3 (3) \\
\hline VIII & Workers in precious metals and electro plate .. & 8,096 & $1(0)$ & $1(0)$ & $0 \quad(0)$ & $0(0)$ \\
\hline $\mathbf{I X}$ & $\begin{array}{l}\text { Electrical apparatus makers and fitters (not elsewhere } \\
\text { enumerated) and electricians }\end{array}$ & 8,236 & $0 \quad(0)$ & - & - & - \\
\hline $\mathbf{x}$ & Makers of watches, clocks, and scientific instruments.. & 768 & $0 \quad(0)$ & - & - & - \\
\hline $\mathbf{X I}$ & $\begin{array}{l}\text { Workers in skins and leather, and makers of leather } \\
\text { and leather substitute goods (not boots or shoes) }\end{array}$ & 1,068 & $0 \quad(0)$ & - & - & - \\
\hline XII & $\begin{array}{llllll}\text { Textile workers } & \ldots & \ldots & \ldots & \ldots & \end{array}$ & 267 & $0(1)$ & $-(1)$ & $-(0)$ & $-(0)$ \\
\hline XIII & Makers of textile goods and articles of dress ... & 3,473 & $0(0)$ & - & -- & - \\
\hline XIV & Makers of foods, drinks, and tobacco..$\quad \ldots$ & 4,151 & 0 (1) & $-(0)$ & $-(0)$ & $-(1)$ \\
\hline $\mathrm{xV}$ & Workers in wood and furniture .. & 17,301 & 0 (0) & - & - & - \\
\hline XVI & $\begin{array}{l}\text { Makers of and workers in paper and cardboard ; } \\
\text { bookbinders, etc. }\end{array}$ & 685 & $0(0)$ & - & - & - \\
\hline XVII & $\begin{array}{lllll}\text { Printers and photographers } & \ldots & \ldots & \ldots & \ldots\end{array}$ & 3,858 & $0(0)$ & 一 & - & - \\
\hline XVIII & $\begin{array}{l}\text { Builders, bricklayers, stone and slate workers ; con- } \\
\text { tractors }\end{array}$ & 17,067 & $4(0)$ & $1(0)$ & $1(0)$ & $2(0)$ \\
\hline XIX & Painters and decorators & 7,820 & $0(1)$ & $-(0)$ & $-(1)$ & $-(0)$ \\
\hline $\mathbf{X X}$ & $\begin{array}{lllll}\text { Workers in other materials } & \ldots & \ldots & \ldots & \ldots\end{array}$ & 3,546 & $1(2)$ & $0(0)$ & 0 (2) & $1(0)$ \\
\hline XXI & $\begin{array}{l}\text { Workers in mixed or undefined materials (not elsewhere } \\
\text { enumerated) }\end{array}$ & 1,962 & $0(0)$ & - & - & - \\
\hline XXII & Persons employed in transport and communication .. & 32,249 & $3(1)$ & $1(0)$ & 0 (1) & $2(0)$ \\
\hline XXIII & $\begin{array}{c}\text { Commercial, finance, and insurance occupations } \\
\text { (excluding clerks) }\end{array}$ & 37,187 & 0 (1) & $-(0)$ & $-(0)$ & $-(1)$ \\
\hline
\end{tabular}

* Figures in brackets are the corresponding figures for scrotal cancer (see Cruickshank and Squire, 1950). 
TABLE 2-continued

\begin{tabular}{|c|c|c|c|c|c|c|}
\hline \multirow[t]{2}{*}{ Order } & \multirow[t]{2}{*}{ Description } & \multirow{2}{*}{$\begin{array}{c}\text { Nos. } \\
\text { Em- } \\
\text { ployed } \\
\text { in } \\
\text { Birm- } \\
\text { ingham } \\
\text { (1931) } \\
\text { Census) }\end{array}$} & \multirow[t]{2}{*}{ Cases } & \multicolumn{3}{|c|}{ Exposure of Cases } \\
\hline & & & & Oil & Pitch & Other \\
\hline XXIV & $\begin{array}{l}\text { Persons employed in public administration and defence } \\
\text { (excluding professional men, clerical staff, and } \\
\text { typists) }\end{array}$ & 2,537 & 0 (1) & $-(0)$ & $-(0)$ & - (1) \\
\hline $\mathrm{XXV}$ & Professional occupations (excluding clerical staff) .. & 7,487 & $0(0)$ & - & - & - \\
\hline XXVI & $\begin{array}{l}\text { Persons professionally engaged in entertainments and } \\
\text { sport }\end{array}$ & 2,155 & $0(0)$ & - & - & - \\
\hline XXVII & $\begin{array}{l}\text { Persons engaged in personal service (including institu- } \\
\text { tions, clubs, hotels, etc.) }\end{array}$ & 9,046 & $0(2)$ & $-(0)$ & $-(2)$ & $-(0)$ \\
\hline XXVIII & Clerks and draughtsmen ; typists & 21,597 & $0(0)$ & - & - & - \\
\hline XXIX & Warehousemen, storekeepers, and packers & 9,701 & $3(1)$ & $1(0)$ & $0(0)$ & $2(1)$ \\
\hline $\mathrm{XXX}$ & $\begin{array}{l}\text { Stationary-engine drivers, dynamo and motor atten- } \\
\text { dants }\end{array}$ & 2,424 & $0 \quad(0)$ & - & - & - \\
\hline XXXI & Other and undefined & 35,617 & $2(2)$ & $1(0)$ & $0(0)$ & 1 (2) \\
\hline \multirow[t]{2}{*}{ XXXII } & Retired or not gainfully occupied & 26,541 & $0(0)$. & - & - & - \\
\hline & Totals & 360,011 & $37(34)$ & $18(12)$ & $6(13)$ & $13(9)$ \\
\hline
\end{tabular}

* Figures in brackets are the corresponding figures for scrotal cancer (see Cruickshank and Squire, 1950).

different categories within the Order, many of the jobs involve exposure to mineral oils. Of our cases in Order VII, 12 were exposed to oil, one to pitch, and three to other agents. Clearly it is impossible in a study of this nature to provide unequivocal proof of the direct causal relationship between oil and cancer. Nevertheless the evidence cited above strongly suggests that exposure to oil is the likely cause of the increased incidence of cancer in metal workers.

In Table 1 is recorded the age of onset of the epithelioma, and the average age of those in each occupational category. There was no significant difference between the average ages of the three categories which were "oil" 60 years (S.E. mean $=3)$; " pitch etc." 61 years (S.E. mean $=7$ ) ; and "other" 61 years (S.E. mean = 3). The average age of all groups was 61 years.

Of the 44 patients in this series, 10 were known to be dead by February, 1951 (the date by which the follow-up had been completed). In three instances it was impossible to confirm that the patient was still alive as the patient was not interviewed. However, of the 10 deaths only four could be attributed to the carcinoma ; in five, death was due to other causes, and in one case the cause of death was not established. Those patients dying from their cancer did so at the following intervals after first reporting : four months, six months, two years five months, and five years eight months. An approximate figure for the mortality due to cancer can therefore be estimated by omitting all patients who reported during the last two years of the period under review. (This also excludes the patient in whom the cause of death was unknown.) This gives 34 patients with four deaths or a case mortality of $12 \%$ (S.E. $=6 \%$ ).

Table 1 also shows whether the patient had any clinical glandular enlargement (axillary or epitrochlear) at the time of first reporting. Of those patients who subsequently died, two had enlarged glands and two were recorded as developing them later. Of the remainder 16 had enlarged glands when they first reported. The fact that the glands were enlarged does not imply that they were secon- 
dary to the cancer as a small proportion which were excised were diagnosed histologically as nonmalignant.

\section{Discussion}

The main interest in these findings lies in a comparison between them and those concerning scrotal cancer previously reported (Cruickshank and Squire, 1950).

It will be seen that the minimum incidence of epithelioma of the hands and forearms among males in Birmingham is 44 per 10 -year-period. The corresponding figure for scrotal cancer is 34 . Provided that the patients reported with the same frequency. the two conditions may be regarded as having approximately the same incidence. It is of interest, however, to compare the relative incidence of scrotal and hand and forearm cancer as reported by different workers. Henry (1947), working from notifications of industrial cancer, found that the site of election for oil cancer was the scrotum, the proportion being approximately $2: 1$. But his figures contained a large proportion of cases notified from the cotton industry. It is possible that the additional factor of the friction to the scrotum encountered during work and the relatively low degree of contamination of the hands and forearms may account for the difference. Smithers (1946) reports a preponderance of arm and hand cases over scrotal in the ratio of $3: 1$ in patients referred for radiotherapy. Jenkins (1948) and Winternitz (1947) both give a ratio of $2 \cdot 5: 1$ for the relative incidence of upper limb and scrotal cancer in pitch and tar workers. In our two series it can be seen that the numbers attributable to pitch and tar in the hand and forearm group were less than in the scrotal group. There were more patients with hand and forearm than with scrotal cancer in the " oil " group, but the difference was not significant (Table 1).

In his analysis of deaths from skin cancer of all sites in England and Wales 1911-1945, Henry (1950) showed that the scrotum was the site of the growth in $7.9 \%$ and the upper limb in $6.1 \%$. Clearly no comparison of the relative incidence of cancer in these sites is valid without reference to the nature of the population under consideration and the presumed causal agents.

Inspection of Table 2 shows that the cases of scrotal cancer tended to occur in the same Orders as did those of hand and forearm cancer. There were seven cases in Order IV and 14 in Order VII. Of the 14 patients with scrotal cancer in Order VII, 11 were workers who had been exposed to oil.

If the two series of patients are considered together it can be seen that 30 cases occurred in
Order VII as compared with 41 in the rest of the population. This number is highly significant statistically $\left(\chi^{2}=8.1 ; P<0.01\right)$ although Order IV with a known high incidence of cancer is included with the "rest of the population".

The increased incidence of cancer of these sites in metal workers is considered to be of importance, particularly as the extensive researches of Henry $(1946,1947,1950)$ have failed to demonstrate any such increased incidence in this group. During the 30-year-period 1920-1949 Henry (1950) showed that only 46 cases of cancer of these sites were notified from the engineering industry. In this area only, during 10 years there were 23 cases in engineering which were notifiable as occurring in workers exposed to oils. Henry's analysis of deaths from scrotal cancer (1946) did not reveal an excessive mortality among metal workers. The number of deaths in our series is too small to allow of reasonable comparisons. It is possible, however, that the cancer risk in the engineering industry has not been long enough in existence for it to become apparent from mortality rates.

The average age of onset of the cancer in the hand and forearm series has been shown to be 61 years, while that in the scrotal series was 55 years. This difference is statistically not significant. Moreover there is no age difference between the three occupational groups in the present series in contrast with the scrotal series. The only important difference in the age of onset of the cancer in each of the three categories of the two series is the earlier onset of the cancer of the scrotum in oil workers. This shows a statistically significant difference from each of the other groups. The age of onset in our present series is less than that reported in a similar series by Johnson and Ackerman (1950), who found that the median age of 71 patients with carcinomata of the hand and forearm was 74 years.

The case mortality has been estimated at $12 \%$ while that from the scrotal cancer has been previously estimated at $38 \%$. This difference, although suggestive, falls just short of statistical significance at the $5 \%$ level. Johnson and Ackerman (1950) report six deaths due to cancer out of 57 cases of hand and forearm cancer treated and followed-up for three years. This figure appears to be very close to our finding.

\section{Conclusions}

It has been demonstrated that a high proportion of epitheliomata of the hand and forearm as well as of the scrotum occur among workers exposed to recognized carcinogenic agents. Ryle demonstrated that persons of the lower income group (Class V, Registrar-General's Report) incurred an increased 
incidence of skin cancer (Ryle, 1947). The work here reported confirms the findings of Henry (1946, $1947,1950)$ that the type of occupation followed is a major factor affecting an individual's likelihood to develop cancer of the skin.

As a considerable proportion of these cancers may occur after the patient has retired from active work, the connexion between work and cancer is often not obvious. Nevertheless it is the responsibility of industrial medical officers and others concerned with occupational medicine to ensure that during the working life minimal exposure to known carcinogenic agents occurs, and that the statutory obligation to notify any cases which may arise is fulfilled.

\section{Summary}

An investigation of the patients treated for epithelioma of the hand and forearm at the United Birmingham Hospitals during the 10-year-period 1941-1950 has been undertaken.

The incidence and case mortality of epithelioma of the hand and forearm have been calculated and discussed.

A significantly large proportion occurs among " metal workers". Exposure to oil is suggested as the probable cause.
The findings are compared with those of a previous similar investigation of scrotal cancer.

We wish to thank the surgeons of the United Birmingham Hospitals who, through the chairman of the Medical Committee, Mr. B. T. Rose, F.R.C.S., gave permission to use their case notes ; and Miss J. M. Levi, follow-up officer, United Birmingham Hospitals, for access to the very complete records in her care.

The majority of the histological sections and reports were prepared under the direction of the late Professor G. Haswell Wilson. We wish to express our indebtedness to Dr. J. G. Jackson who checked the diagnoses in such sections as were available. We also wish to acknowledge the continued interest and advice of Professor J. R. Squire, Leith Professor of Experimental Pathology, University of Birmingham.

\section{REFERENCES}

Census of England and Wales (1931). Occupation Tables. H.M.S.O., London.

Cruickshank, C. N. D., and Squire, J. R. (1950). British Journal of Industrial Medicine, $7,1$.

Henry, S. A. (1946). "Cancer of the Scrotum in Relation to Occupation." London.

-(1947). Brit. med. Bull., 4, 389.

(1950). Ann. roy. Coll. Surg. Engl., 7, 425.

Jenkins, W. D. (1948). " Dermatoses among Gas and Tar Workers." Bristol.

Johnson, R. E., and Ackerman, L. V. (1950). Cancer, 3, 657.

Ryle, J. A., and Russell, W. T. (1947). Brit. med. J., 1, 873.

Smithers, D. Waldron (1946). "The $X$-ray Treatment of Accessible Cancer." London.

Winternitz, J. G. (1947). Brit. J. Radiol., 20, 158. 